\title{
Enhancing Chinese Students' Learning in an Australian 2+2 Undergraduate Engineering Program
}

\author{
Peter Doe ${ }^{1}$, Sarah Lyden ${ }^{1}$, Seeta Jaikaran-Doe ${ }^{1} \&$ Xiaolin Wang ${ }^{1}$ \\ ${ }^{1}$ School of Engineering, University of Tasmania, Australia \\ Correspondence: Peter Doe, School of Engineering, University of Tasmania, Private Bag 65, Hobart Tasmania, \\ Australia, 7001. Tel: 61-42-481-9820.E-mail: peter.doe@utas.edu.au
}

Received: September 12, 2018

Accepted: September 24, 2018

Online Published: September 26, 2018

doi:10.5430/ijhe.v7n5p86

URL: https://doi.org/10.5430/ijhe.v7n5p86

\begin{abstract}
Undergraduate engineering units (subjects) are delivered by Australian academics at two universities in China over a three-week period. Students may choose to transfer to the Australian university to complete the final two years of the Bachelor of Engineering with Honours degree $(2+2$ program). The aim of this study is to determine what strategies are most effective for the Australian university academics to adopt for effective delivery of engineering units at Chinese universities. A mixed methods approach was applied to in-class feedback and student surveys. Three major themes: Language, Learning and Social were identified. These themes were further explored in a quantitative survey of Chinese students newly-arrived in Australia in 2016. Successful strategies for delivering engineering units included referring questions to discussion groups; students explaining difficult concepts to other students; writing key words on the board and flash cards. The principal concern for students before they transferred to Australia was the teaching and learning style of the Australian university academics. However, English language proficiency was the major concern for students transferred to Australia. The strategy for improving Chinese students' engagement and learning outcomes should focus on additional support both in China and Australia.
\end{abstract}

Keywords: Chinese students, engagement, engineering undergraduates, learning, language, Australian university

\section{Introduction}

This study examines the experiences of Australian academics delivering engineering content at two universities in the People's Republic of China. Two years into a four-year engineering degree at their home universities, the Chinese students may choose to transfer to a regional Australian university to complete a Bachelor of Engineering with Honours degree for a further two years $(2+2$ program). These students move from a familiar and regimented life to a very different culture and learning style taught in a different language. Not surprisingly, many of the students perform poorly in their first semester of study in Australia.

The Australian academics teaching in China in the $2+2$ program are typically confronted by 100 or more students sitting at fixed desks. Second year Chinese students' command of the English language is not sufficiently developed to be able to follow a typical Australian 'lecture'. The Australian academics are able to engage with the few students sitting in front of the class but most of the students are not able to understand what is being said. Many try to follow the lecture notes that the lecturer had posted in advance on the students' learning website; the more assiduous students would have pencilled in translations of technical terms. Some students use their mobile devices to translate technical terms while the lecturer is speaking. Towards the back of the classroom students play computer games, text their friends or fall asleep.

From the start of formal schooling Chinese students are expected to be passive learners (Loh \& Teo, 2017). Attendance in class is mandated. Students learn to respect their academics and not to question the validity of their teachings. The challenge for the Australian academics is to prepare these students for the very different student-centered teaching and learning style they encounter when transferring to Australia. Accordingly, the Australian academics attempt to engage the students. In 2015 a teacher in an engineering design and project management class sought feedback from a cartoon video that had just been shown. The teacher walked to the center of the class (105 students) and asked the question: "Who thought that video was interesting". There was no response. "OK", he said, "who thought that video was funny?" Again, no response. After receiving no response to the third question: "Who has understood anything I have 
just said?" the teacher realized that there was a problem with engagement and communication. The teacher's subsequent action and the students' responses are detailed under the result section below.

\subsection{Literature Review}

Chinese students studying in Australia make a significant contribution to the income stream of higher education institutions (Australian education exports top AUS $\$ 19$ billion in 2015, 2016). In some classes there are more international students than local students. Marketing of universities is highly competitive both within Australia and internationally. There are many factors influencing which university or country a student will choose. Australian academics teaching engineering in China are well placed to influence that choice.

A considerable amount of research has been conducted on international students when transitioning to Australian universities (Birrell, 2006; Ramburuth \& McCormick, 2011). Motivation of students to study in Australia, social and cultural adjustment, and academic adjustment are common themes in previous research (Malau-Aduli, 2011). Sawir, Marginson, Deumert, Nyland and Ramia (2008) reported that a majority (two thirds) of 200 Chinese students studying in Australia had experienced 'problems of loneliness and/or isolation, especially in the early months'. In a study of international students' academic and cultural experiences in the UK, Bamford (2008) examined how language, social and cultural issues impacted on learning processes.

Whereas Australian universities adopt the independent learner model, Chinese universities typically follow more of a parent-child relationship between the teacher and student. Stereotypically, Chinese student learning styles are considered to be surface learning approaches where the student is a passive participant (Wong, 2004). However, the reflective nature of Chinese learners in developing a deeper understanding than what may be apparent from classroom participation is also documented (Bowden, Abhayawansa \& Manzin, 2015; Lu, Chin, Yao, Xu \& Xiao, 2010).

The view that international students are surface learners, not willing to engage in class, and prefer the company of their cultural peers has been challenged (Kember, 2000). The Chinese education system is designed to facilitate large classes. Students are taught from young to respect their academics; thus, there is little/no disciplinary problem in the classroom. Content is delivered in a manner that may appear to outsiders to be rote learning, but students learn to repeat and memorize content for understanding. Since most students at tertiary level live on campus in China, there is a strong peer support as well as access to academics outside the classroom (Lee, 1996). As a result, students have the potential to develop deep approaches in learning.

Australian academics teaching in China are responsible for preparing students for study in Australia. Typically, the first interaction the Chinese students have with Western styles of teaching is with the visiting Australian academics. However, the degree of interaction is limited by the facilities available at the university, timetabling and the intensive, short duration of content delivery. Yang (2008) suggests that Australian universities need a sound understanding of the Chinese context to ensure that high quality transnational educational programs are provided. Understanding the cultural context that students transitioning to Australia come from is also beneficial in determining how best to help these students adjust to the Australian context. Degree programs should be planned to accommodate Chinese students' lack of fluency in technical English, cultural differences and different teaching and learning styles (Heffernan, Morrison, Basu \& Sweeney, 2010; Holmes, 2004).

In a study involving non-Chinese academics of English at a Chinese University, Wang (2011) found 'Chinese students are afraid of standing out from the crowd: Chinese students expect that the academics' role is to transmit information rather than engage students in dialogue and challenging students to think'. In another study involving Chinese students studying nursing in Australia, Wang, Andre \& Greenwood (2015) reported Chinese students also show a reluctance to speak up during class which may be a lack of confidence to communicate in English in front of their peers, or of not having the correct answer.

\subsection{Research Questions}

Understanding the potential reasons for the high initial failure rate for students in their first semester and implementing appropriate support structures are important strategies towards ensuring the wellbeing of international students transitioning to Australia and the longevity of the $2+2$ programs.

There is still a lack of understanding of which factors limit Chinese students' study in their first semesters of study in a $2+2$ program in Australia. In this study a mixed methods approach is used to investigate what can be achieved before the students transfer. 
The following Research Questions are proposed:

1) What practices/strategies/interventions are most effective for Australian university academics to adopt to enhance/promote more effective delivery of engineering units at the Chinese partner universities?

2) What factors limit the effective delivery of Australian university engineering units at the Chinese partner universities?

\subsection{Delivery of Engineering Content in China}

From 2012 teachers from a regional Australian University have been delivering engineering units (subjects) at universities in China; the word 'teacher', lăoshì in Mandarin, is commonly used as a post nominal for any person lecturing or tutoring at a Chinese university. Four of the teachers were profile staff, the rest were undergraduate and postgraduate candidates, and retired academics. In all there have been 35 such visits since the signing of the agreement with a Chinese university (designated ChineseUniX) in 2010. Australian teachers began teaching at another Chinese university (ChineseUniY) in November 2015. Only one teacher, a staff member who taught at ChineseUniY in May 2016, was fluent in the Chinese language.

Until September 2016, all the teaching by Australian academics followed the traditional lecture-style, teacher-centered, practice of face-to-face delivery of 72 hours' content together with tutorial sessions and laboratory work in the ratio 39 hours lectures: 13 hours tutorials: 20 hours laboratory (or design studio). Content, and intended learning outcomes, were identical to that delivered in Australia (on-shore). But there were changes to assessment in some units to compensate for students' English language proficiency. Up until May 2015 the 72 hours in each unit were delivered off-shore over a two-week (10 day) period with mostly 8 hours face-to-face contact each day. From May 2015 the 72 hours were delivered over a three-week ( 15 day) period.

The Australian teachers were responsible for the planning, designing and delivering of content. In the first years of the delivery at ChineseUniX only very limited pedagogical guidance was provided from the more experienced teachers as they themselves had little or no experience of teaching in China. Hard copies of on-shore lecture notes and tutorial problems were made available to teachers teaching the units off-shore. These materials formed the basis of the delivery by the less experienced teachers. The more experienced teachers were able to modify the teaching materials by including translations of technical terms. However, the delivery was traditional teacher-centered didactic teaching with the teacher 'lecturing' to the class from a raised dais with little or no student engagement.

Practical work was undertaken in specially equipped laboratories. Chinese teachers and/or laboratory technicians were mostly present for lectures, tutorials and laboratory sessions. Apart from laboratory instructions prepared by the Australian teachers all other documentation in laboratories as well as equipment labelling was in the Chinese language. The Chinese teacher in the class generally played a passive role - checking attendance and making announcements in Chinese language, particularly announcements concerning class locations and assessments.

\subsection{Teacher-Centered Learning}

The term teacher-centered learning is used to describe the traditional didactic learning and teaching practice in China (off-shore). There were large classes (typically 70 - 100) at both Chinese universities with students sitting in rows of fixed seating. The teacher delivered content knowledge, in the English language, from a raised dais in front of a blackboard. The available resources for teachers include mainly a stationary computer in the class, document camera, video projector, and a sound system. PowerPoint slides, videos and the emphasis of important points by writing (with chalk) on a blackboard were the major delivery tools. It was the norm that in-class engagement was limited to students sitting in the front rows with the best English language skills.

\subsection{Student-Centered Learning}

One of the more experienced Australian teachers (PD) initially used a mix of 'chalk and talk', PowerPoint slides, and videos for the delivery of content. English words that had a particular technical meaning were written on the black board. The meanings of technical words were explained, and sometimes a student was handed the chalk and invited to write the word on the board as a character and in pinyin. The teacher attempting to pronounce the word invariably brought forth howls of laughter.

In April 2016, an experienced pedagogue (S J-D) conducted a peer review of PD's teaching in a class of over 100 students. She suggested the following learning strategies to encourage class participation and deeper understanding:

- Students should prepare questions and answers related to concepts that were previously taught. Then a student would name a friend who had to respond to one of the prepared questions. 
- Students should work in groups. Each group was given a concept to discuss and then when the time is up, the spokesperson for each group would explain the meaning and application of the concept.

- Students can be shown a word related to a concept. They write what they know about the word in relation to what they had previously learned. Students were then called upon to present what they had written.

Techniques also found to be effective in facilitating student-centered learning were:

- $\quad$ Directing questions to individual students

- Handing a piece of chalk to a student and inviting them to write on the black board

- Inviting a student to come to the front of the class and explain important concepts (in English and/or Chinese)

- Using flash cards to reinforce technical words

- $\quad$ Referring questions to discussion groups

\section{Method}

\subsection{Research Design}

Because Australian academics are not permitted to survey student opinion of their teaching in China a mixed methods approach was employed to assess the effectiveness of strategies to develop student-centered learning.

\subsection{Qualitative Research}

The qualitative component was in-class feedback on communication effectiveness provided by Chinese students $(\mathrm{N}=105)$ in one of the author's classes at ChineseUniX in May 2015. In addition, Lyden (2016) had surveyed relevant student opinions from a survey of students from ChineseUniX who had already transferred to Australia ( $\mathrm{N}=22$ ). These qualitative data were analyzed using NVIVO.

\subsection{Quantitative Research}

Ethics approval was granted by the Australian university to survey newly arrived Chinese students who had articulated into, and were enrolled in, the Bachelor of Engineering with Honours program. The survey instrument comprised 16 questions selected from a paper-based, valid and reliable, survey in the public domain - Student Evaluation of Teaching and Learning (SETL) (Student Evaluation of Teaching Manual, 2003).

Students were required to respond to each question on a 7-point Likert scale from 0 to 6 with $0=$ Strongly Disagree and 6 = Strongly Agree. To assure that the newly arrived students fully understood the survey it was prepared in both English and Mandarin. No written responses were sought.

\section{Results}

\subsection{In-Class Feedback (Off-Shore)}

In 2015 an Australian teacher at ChineseUniX sought feedback from the class on a cartoon video on project management that had just been shown. As related in the Introduction the teacher realized that there was a problem with engagement and communication. The teacher directed the students to assemble into their laboratory groups $(8$ students per group) and after 10 minutes write three suggestions on the blackboard how to improve communication in this class; this in-class feedback is shown verbatim in Table 1.

A review of literature identifies many factors affecting students' performance after transitioning to study in Australia including social and cultural differences, lack of technical language fluency and the change in learning and teaching (L\&T) styles. Three themes, Language, Learning and Social emerged from an earlier qualitative survey of Chinese students newly transitioned into the Australian engineering degree (Lyden, 2016).

The results of the NVIVO autocoding function applied to students' responses to the in-class feedback (Table 1) are shown in Figure 1. The coding words relating to Learning identified in the responses were: study, questions, understand, classroom, example, teacher, information. The majority opinion of these students (still in China) was that the learning style of the Australian university academics was more important than the students' English language proficiency. 


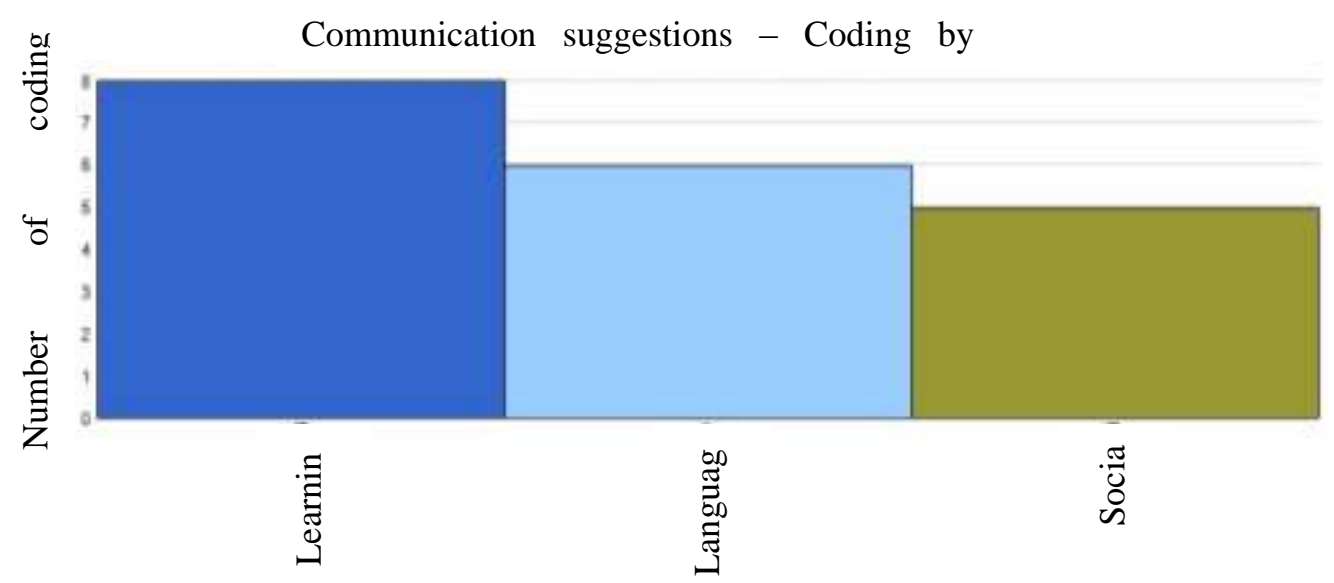

Figure 1. The number of references related to Learning, Language and Social in Table 1.

Table 1. Suggestions to improve communication between Australian Teacher and Chinese students

Transcription of students' comments from blackboard

Use some simple words and speak slowly. We study English

Use pictures instead of speaking English

Play some simple games to improve atmosphere

Have more passion and some body language

Emphasize the keyword

Ask students to express their idea after teacher tell us something

Dinner outside to discuss interests

Write down the complex words if necessary and we can use the dictionary in the cell phone

The teacher can speak clearly and I hope the teacher can give the students some time to

Ask questions individually writing standard

We should boldly speak English, don't be shy

Write down what you say if you feel that we don't understand what you say

Can you talk with our Chinese teacher, if we don't respond to you, may our Chinese teacher

Make our class atmosphere happily and talk about with students frequently

Let us Chinese teacher translate the question if it is important

Speak more slowly and simple words please

Enrich classroom content, do many examples

Active classroom atmosphere, ask much question

Key words write on blackboard

Use some body language if we don't understand you

Use some simple words or pictures to replace difficult words

More communicate with students

Give us many vivid example

We could understand by using easily words

Using body language makes us understand what you say

We think teacher should participate more in the production process and vive more advices

It would be easier for us if you provide some webs for us to search information

\subsection{Student Opinion (On-Shore)}

Lyden (2016) surveyed Chinese students $(N=22)$ who had transferred to Australia and were enrolled in the third- and fourth-year units. These students had previously completed two years of an electrical engineering degree course at ChineseUniX. Although this study identified some of the reasons for students' poor performance in their first semester 
in Australia it also probed their learning and teaching experience at Chinese Universities before coming to Australia. The two questions relevant to the subject of this research were:

Q3. Which factor has been most difficult to adjust to in studying at Australian university?

Q7: What expectations did you have before coming to Australia to study? What has been most challenging since you arrived?

In response to survey Question Q3, 68\% of the students responded 'Language', 18\% responded 'Teaching and Learning Styles', 10\% responded 'Social' and the remaining student responded 'Other - I think they are all problems when I first came here'.

The Chinese students' responses to survey Question Q7 are shown in Table 2. The same coding (as for the in-class feedback) was used: 'Language', 'Learning', and 'Social'. The results of the NVIVO autocoding function applied to students' responses to Question 7 using these three coding patterns are shown in Figure 2.

Table 2. Responses to questions: What expectations did you have before coming to Australia to study? What has been most challenging since you arrived?

\section{Students' responses}

Difficulties fall into getting across jargons which are involved in the class and the jokes which (Australian teacher) has made

Honestly, I expected a friendly study environment in (Australian University) and I did have a quite good study experience so far. I think most local students are very nice and friendly and ready to help us. I think language and culture difference are the most challenging things.

I wanted to study a new culture, and the difficult is language.

I expected for working with local students all the time, the results are good enough. I consider the most challenging thing I ever meet is getting along with other roommates in the rented house.

Lack of fundamental knowledge of first two years' units and English

Language!!!!!! I think the most challenging is English!!!! some tutor said

Language, I think I can understand what the people say, but it is not. And I cannot understand the professional engineering words when having lectures.

The expectation I have before coming here is to get a better learning process and getting more advanced knowledge. Yes, (this university) provided me sufficient of those I mention. The most challenging thing I met is the education methods, the content is not the same so there is a lot of prerequisite that I need to learn by myself which make my first semester terrible because I have to keep up with the lectures up to date and also to learn the knowledge previously the classmate already learned.

The most difficult thing is language barrier and I expect to learn more useful knowledge which is not learned in China.

To be honest, the hardest challenge i have met is that whatever methods I tried, there are lots of contents that I can't understand and I can't explain it by myself directly. But this situation become much better and i need to thanks teacher's helps. Before coming to AU, I have a strong ambition about improve English in a short period and can touch more up-to-date knowledgeable, but everything need time to make effect on.

1. get good grades 2. language and food.

Poor language

English problem

1. I want learn more knowledge in Australia. 2.The biggest challenge in language problem, I can't understand all the words in class because there are many professional words.

Environment has changed

Improve me in professional knowledge, language

Success in study, in life arranging and communication. 
The results of the NVIVO autocoding function applied to the data in Table 2 are shown in Figure 2. It should be noted that the students participating in this survey had already transferred to the Australian university and had experienced life in Australia and study in the Australian university engineering course. Although the first part of the survey question 'What expectations did you have before coming to Australia to study?' related to the students' experience at ChineseUniX, the second part of the question: 'What has been most challenging since you arrived?' was not relevant to the students' experience in China. However, it is revealing that these students reported that language was more important than learning styles.

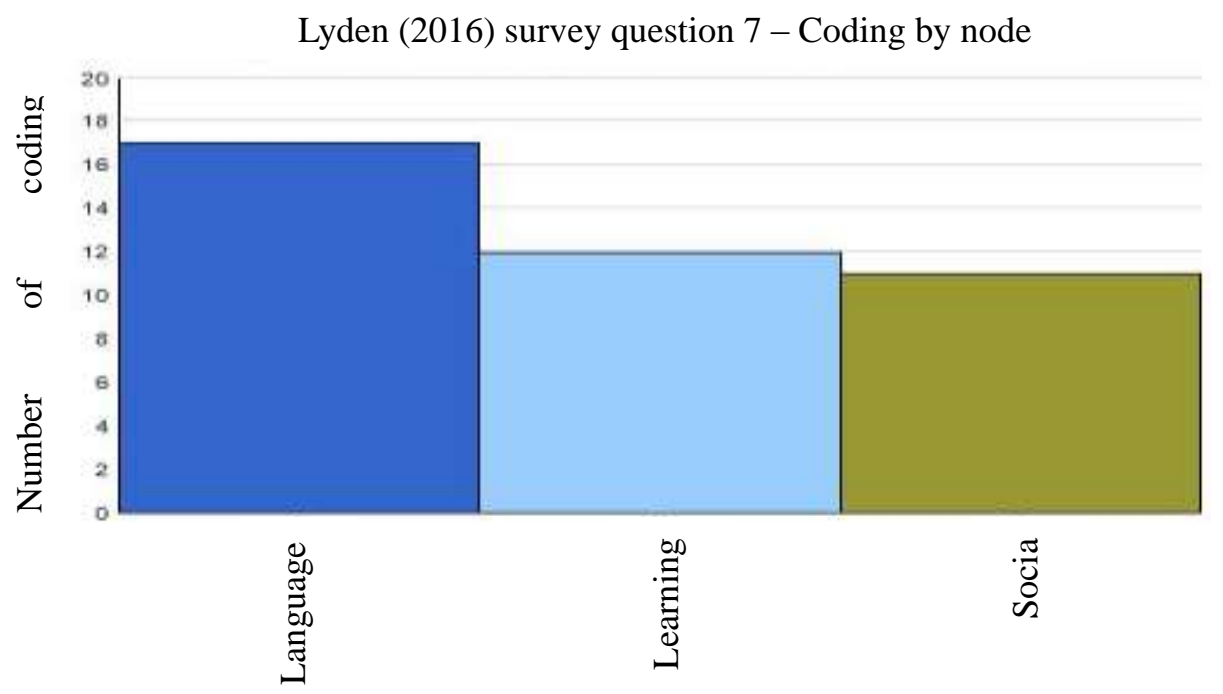

Figure 2. The number of references related to the three identified major themes; Learning, Language and Social

\subsection{On-shore Student Evaluation of Off-Shore Learning and Teaching}

Eighteen students from ChineseUniX completed the quantitative survey on 21 October 2016. These students were all enrolled in an English language program at the Australian university and had been resident for periods of five to 20 weeks according to their English language proficiency on arriving.

Another 12 students from ChineseUniY completed the survey on 11 October 2016. These students termed 'direct entry students' had all met the required English language proficiency through study in China before articulating directly into their engineering study at the Australian university. It is a requirement for admission to their engineering course at the Australian university that all international students must have achieved the equivalent of IELTS level 6, with no band below 5.5.

\subsubsection{Comparison of SETL responses - Chinese Universities}

An unpaired, two-tailed, equal variance $t$-test comparing all the survey results from newly-arrived students from the two Chinese universities showed there to be no significant difference at the $95 \%$ probability level; Overall $d f 476, S D=$ $0.859, t=-1.74, p=0.083$. Means and standard deviations of scores for the two cohorts were:

- ChineseUniX, $d f=287, M=5.24, S D=0.84$

- $\quad$ ChineseUniY, $d f=189, M=5.10, S D=0.89$

\subsubsection{Responses to SETL Questions}

An Analysis of Variance (ANOVA) (Kirkman, n.d.) was conducted on each cohort with the aim of identifying any significant differences between responses to the 16 survey questions. In the case of ChineseUniY, no significant differences in survey question responses were identified at the $95 \%$ probability level $(d f=15, F=1.34, p=0.18$ ).

The students from ChineseUniX, however, responded with a significantly better response $(d f=15, F=3.096, p$ $<0.0001)$ to Question I namely The Australian university lecturer in China encouraged team work $(M=6.0 S D=0.0$ Strongly Agree) (Figure 3). This result can be attributed to one of the Australian teachers forming groups of about 8 students for design classes and assessing the work of each group. When Question I was removed from the ANOVA there were significant differences between the responses to the remaining fifteen survey questions at the $95 \%$ probability level $(d f=14, F=1.94, p=0.023)$. An unpaired, two-tailed, equal variance t-test of the results (with 
Question I excluded) suggests that Question H The Australian university lecturer in China encouraged student creativity $(M=5.6 S D=0.8)$, might be a significantly better result than the responses to all the other questions ( $\mathrm{p}=0.056)$. The least favourable response (Question A, $M=4.84 S D=0.8$ between Agree and Moderately Agree) showed no significant difference $(t$-test) from the other questions $(p=0.08)$.

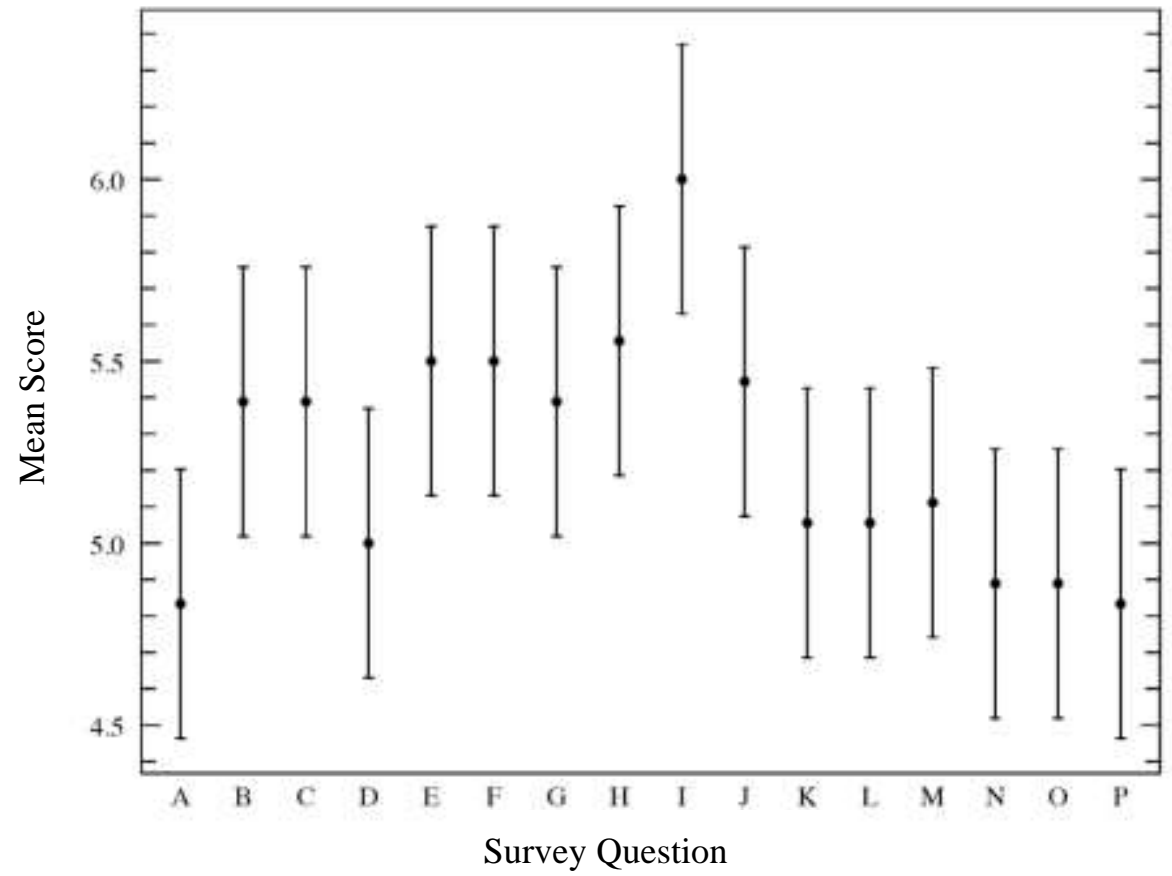

Figure 3. ANOVA showing means and 95\% confidence limits for responses to SETL survey for ChineseUniX.

3.3.3 Comparison of SETL Survey Responses to The Identified Major Themes Language and Literacy

Two of the three major themes identified by the NVIVO analysis of the qualitative data Language and Learning, were investigated using the SETL quantitative data. There were no questions in the survey that directly related to the third major theme, Social. Cultural and social issues were not relevant to the students before coming to Australia.

The SETL survey questions directly relating to students' Language proficiency are:

Question A: The Australian university teacher in China communicated effectively

Question B: The Australian university teacher in China spoke clearly

Question F: The Australian university teacher in China encouraged students to express their ideas

Question G: The Australian university teacher in China encouraged student discussion

Question J: The Australian university teacher in China provided opportunities for students to ask questions

Question P: In (my) classes in China I put a lot of effort into learning for the topic

The SETL survey questions directly related to Learning:

Question C: The Australian university teacher in China made effective use of teaching materials

Question D: The Australian university teacher in China emphasised the important points

Question E: The Australian university teacher in China taught in a way that facilitated my learning

Question H: The Australian university teacher in China encouraged student creativity

Question I: The Australian university teacher in China encouraged team work

Question K: In (my) classes in China the tutorials assisted me in the understanding of the content of the lectures

Question L: In (my) classes in China my group succeeded in working as a team

Question M: In (my) classes in China I liked working in a group

Question N: In (my) classes in China I understand the concepts presented in the topic

Question O: In (my) classes in China I am able to identify the important points 
An unpaired, two tailed, equal variance, $t$-test comparing all the survey results for the Language questions with the survey results for the Learning questions showed that although the mean score for Language $(M=5.22 S D=0.8)$ was slightly higher than that for Learning $(M=5.16 \mathrm{SD}=0.9)$ the difference between the mean scores was not significant at the $95 \%$ probability level $(p=0.42)$.

\section{Discussion}

\subsection{Outcomes}

The strategies and techniques shown to be most effective in delivering engineering units off-shore by encouraging student engagement (Research Question 1) are described above. Getting students to form groups facilitated participation in lectures. Evidence for this is the very high approval rating of the Australian lecturers' teaching in China. Students from ChineseUniX gave a mean score $M=5.10, S D=0.89$ for all questions in the survey $(N=190)$ which is between 'Moderately agree' and 'Strongly agree' on the 7-point Likert scale $(0=$ 'Strongly disagree', $6=$ 'Strongly agree'). Students from ChineseUniY gave a similar result $M=5.24, S D=0.84, N=288$.

The response from the students $(N=18)$ from ChineseUniX to the survey question 'The Australian university lecturer in China encouraged teamwork' received the highest rating with mean score ( $M=6.0 S D=0.0$ Strongly Agree). The lowest rating (Agree to Moderately Agree) was from students from ChineseUniY $M=4.33, S D=1.15$ to the survey question 'The Australian university lecturer in China made effective use of teaching materials'; one student responded with a score of 2 (Disagree) to this question.

The principal factors that limit the effective delivery of Australian university engineering units at the Chinese partner universities (Research Question 2) were found to be communication (language) and teaching style (learning). Before they transferred to Australia the teaching style was of more concern (Figure 1) according to the qualitative survey. After transferring to Australia, however, the Chinese students discovered that their English language proficiency was not adequate, in particular their understanding of technical English (Figure 2). This conclusion (from the qualitative research) was not supported by the quantitative survey administered to students a few months after articulating to the Australian university. Perhaps the students' experience in Australia was such that both language and learning were equally important.

Students were strongly supportive of group work. Also, there is some evidence from the results of the quantitative survey the Australian university lecturers were effective in encouraging student creativity.

\subsection{Ongoing and Future Research}

There is still a lack of understanding of the factors limiting Chinese students' performance in their first semesters of study in a 2+2 program in Australia. Cultural and most importantly language differences have been identified as the main causes of students failing units in their first semester in Australia. The survey of Chinese students' performances in their first semester of study at the Australian university conducted by one of the authors (SL) in February 2016 is the first part of a longitudinal study which will track the performance of all students articulating from Chinese universities into the Australian university.

Intensive Mode Teaching (IMT) techniques (Male et al., 2016) were trialled by Australian university academics at both Chinese universities from September 2016 (Doe et al., 2017). The following strategies/factors/interventions were introduced:

- Provision of lecture notes prior to delivery

- Use of discussion boards.

- Strategies to facilitate student engagement in lectures and laboratory/design classes

- On-line formative assessment games

- In-class Learning and Teaching interventions

- Use of on-line learning management system

- Structured teams

- Reasonable adjustment for assessment

The effectiveness of interactive IMT delivery of an Engineering Design and Project Management class was evaluated through students' performance in summative assessment tasks aligned to Intended Learning Outcomes. The 2016 class $(\mathrm{N}=194, \mathrm{M}=85.9 \%, \mathrm{SD}=12.3 \%)$ performed significantly better $(\mathrm{p}<0.0001)$ than the 2017 class $(\mathrm{N}=186, \mathrm{M}=77.8 \%$, $\mathrm{SD}=12.8 \%$ ). With a Cohen's $\mathrm{d}$ of 0.645 this be considered as a "large effect size". This unexpected result was attributed 
to Chinese students' long exposure to didactic, teacher-centred, learning together with difficulty in reading and understanding content in the English language delivered on-line prior to the face-to-face classes.

Adjusting to language was the most difficult factor for newly-arrived Chinese students identified in this study. It would be interesting to conduct further research to identify exactly what aspects of language the students find the most challenging and what mitigation strategies are most effective. Would bi-lingual academics be better communicators? Is the problem a lack of fluency in technical English; the speed at which the lecturers and fellow classmates talk; or difficulty in adjusting to different accents?

There are more international than domestic students in some engineering classes. Strategies for promoting cultural diversity within student laboratory groups are currently being investigated (Doe et al., in press).

\subsection{Recommended Interventions/Strategies for Better Preparing Chinese Students for Study in Australia.}

This research has confirmed the widely held view that lack of fluency in the English language is the prime cause of poor performance of Chinese students in their first semester studying engineering in Australia. Engaging with the students has proven difficult due to large class sizes in China and the ingrained culture of passive learning. Australian academics teaching in China should use the techniques described above to create a student-centered environment in class to better prepare them for study in Australia. One very effective technique is to encourage group work - students learn from their peers. Besides, there is not the fear of failure to communicate when one student is supported by others in his or her group.

Chinese students in their first semester in Australia rate language proficiency more important to successful study than lecturers' teaching style. This observation has led to the appointment of Australian academics who work in China teaching English language focussing on writing engineering laboratory reports, gaining better knowledge of technical English, and developing oral communication skills.

\subsection{Conclusion}

This study was the start of research focussing on a better outcome for Chinese students entering a $2+2$ program at an Australian university. The methods developed for Australian academics to engage students with a spectrum of English language skills in large classes, together with a program of support for newly articulated students have proven to be effective (Jaikaran-Doe, Lyden \& Doe, in press). The Australian university is now accepting students from a third Chinese university.

\section{References}

Australian education exports top AUS\$19 billion in 2015. (2016). Retrieved from http://monitor.icef.com/2016/02/australian-education-exports-top-aus19-billion-in-2015/

Bamford, J. (2008). Strategies for the improvement of international students' academic and cultural experiences of studying in the UK. The enhancing series case studies: international learning experience: The Higher Education Academy.

Birrell, B. (2006). Implications of low English standards among overseas students at Australian universities. People and place, 14(4), 53.

Bowden, M. P., Abhayawansa, S., \& Manzin, G. (2015). A multiple cross-cultural comparison of approaches to learning. Compare: A Journal of Comparative and International Education, 45(2), 272-294. https://doi.org/10.1080/03057925.2013.841465

Doe, P., Jaikaran-Doe, S., Lyden. S., Liu, M., Ren, B., Yang, P. \& Male, S. (2017) Intensive Mode Teaching for the delivery of engineering content to students at a Chinese University. AAEE2017 Conference, Manly, Sydney, Australia. Retrieved from: https://eprints.utas.edu.au/26978/1/AAEE2017-FINAL\%20Camera\%20Ready.pdf

Heffernan, T., Morrison, M., Basu, P., \& Sweeney, A. (2010). Cultural differences, learning styles and transnational education. Journal of Higher Education Policy and Management,32(1), 27-39. https://doi.org/10.1080/13600800903440535

Holmes, P. (2004). Negotiating differences in learning and intercultural communication: Ethnic Chinese students in a New Zealand university. Business Communication Quarterly, 67(3), 294-307. https://doi.org/10.1177/1080569904268141

Jaikaran-Doe, S., Lyden, S., \& Doe P.E. (in press). Articulation of Chinese Students into an Australian Engineering Degree. AAEE2018 Conference, Hamilton, NewZealand. Dec 9-12. 
Jaikaran-Doe, S., León de la Barra, B., Lyden, S., Wang, I., Fan, F., Henderson, A., Franklin E. \& Doe, P.E. (in press). Strategies for promoting cultural diversity within student laboratory groups in an engineering degree course at an Australian university. AAEE2018 Conference, Hamilton, NewZealand. Dec 9-12.

Kember, D. (2000). Misconceptions about the learning approaches, motivation and study practices of Asian students. Higher education, 40(1), 99-121. https://doi.org/10.1023/A:1004036826490

Kirkman TW, (n.d.). Statistics to Use. Retrieved from http://www.physics.csbsju.edu/stats/

Lee, W. O. (1996). The cultural context for Chinese learners: Conceptions of learning in the Confucian tradition. The Chinese learner: Cultural, psychological and contextual influences, 34, 63-67. https://doi.org/10.1080/00220272.2012.739801

Loh, C. Y. R., \& Teo, T. C. (2017). Understanding Asian Students Learning Styles, Cultural Influence and Learning Strategies. Journal of Education \& Social Policy, 7(1), 194-210.

Lu, J., Chin, K. L., Yao, J., Xu, J., \& Xiao, J. (2010, January). Cross-cultural education: learning methodology and behaviour analysis for Asian students in IT field of Australian universities. In Proceedings of the Twelfth Australasian Conference on Computing Education-Volume 103 (pp. 117-126). Australian Computer Society, Inc.

Lyden, S. (2016). International student perceptions and experiences of studying their final two years of engineering in Australia. Unpublished manuscript.

Malau-Aduli, B. S. (2011). Exploring the experiences and coping strategies of international medical students. BMC medical education, 11(1), 40. https://doi.org/10.1186/1472-6920-11-40

Male S., Ballie C., Hancock P., Leggoe J., MacNish C., Crispin S., Ranmuthugala D. \& Alam, F. (n.d.). Intensive Mode Teaching Guide. Retrieved from http://www.ecm.uwa.edu.au/staff/learning/research/intensive-mode-teaching

Ramburuth, P., \& McCormick, J. (2001). Learning diversity in higher education: A comparative study of Asian international and Australian students. Higher education, 42(3), 333-350. https://doi.org/10.1023/A:1017982716482

Sawir, E., Marginson, S., Deumert, A., Nyland, C., \& Ramia, G. (2008). Loneliness and international students: An Australian study. Journal of studies in international education, 12(2), 148-180. https://doi.org/10.1177/1028315307299699

Student Evaluation of Teaching Manual. (2003) Staff Development and Training Unit, Flinders University. Retrieved from: http://www.flinders.edu.au/Teaching_and_Learning_Files/Documents/fu_set_manual.pdf

Wang, L. (2011). Foreign English Academics in the Chinese Classroom: Focus on Teacher-Student Interaction. The Journal of ASIA TEFL, 8(2), 73-93.

Wang, C. C., Andre, K., \& Greenwood, K. M. (2015). Chinese students studying at Australian universities with specific reference to nursing students: a narrative literature review. Nurse Education Today, 35(4), 609-619. https://doi.org/10.1016/j.cnre.2017.03.002

Wong, J. K. K. (2004). Are the Learning Styles of Asian International Students Culturally or Contextually Based? International Education Journal, 4(4), 154-166.

Yang, R. (2008). Transnational higher education in China: Contexts, characteristics and concerns. Australian Journal of Education, 52(3), 272-286. https://doi.org/10.1177/000494410805200305 